\title{
A vaddisznó (Sus scrofa) zárttéri tartásban fellépö viselkedési problémái
}

\author{
KOVÁCS VIRÁG ${ }^{1^{*}}$ ÚJVÁRY DÓRA ${ }^{2}$ ÉS SZEMETHY LÁSZLó ${ }^{1}$ \\ ${ }^{1}$ Szent István Egyetem, Vadvilág Megőrzési Intézet, 2103 Gödöllő, Páter Károly utca 1. \\ "E-mail: kowirag@gmail.com \\ ${ }^{2}$ Horkai Zoltán Állatkoordinációs Központ, 1132 Budapest, Visegrádi utca 53.
}

\begin{abstract}
Összefoglalás. A vaddisznó a vadgazdálkodás számára jelentős bevételt jelent, szabadterületen állománya folyamatosan nő; a vaddisznós kerti vadászat iránti igényeket mégis egyre nehezebb teljesíteni, habár a kertben lévő állományok nagy része befogásból származik. Ahhoz, hogy a pár napos vadászat során a kertet üzemeltetők biztosítani tudják a vendégek által „elvárt” nagy terítékủ vadászatokat, nagy létszámban kell tartaniuk a vaddisznókat. Ez pedig sokszor nagy állománysürüséggel is párosul, aminek oka a kis, általában 200 és 500 hektár közötti kiterjedésü terület. Zárt tartásban, legyen az vadászati célú kert, vagy hústermelést szolgáló farm, a speciális életkörülmények miatt az egyedek viselkedése meg fog változni a szabadterületi társaikhoz képest. A vizsgálat során szabadterületi és kerti állományok, kondák viselkedésbeli különbségeit vizsgáltuk egy táplálék-kompetíciós helyzetben, rávilágítva így azokra a lehetséges okokra, amelyek miatt a kertek többsége nem önfenntartó, az ottani szaporulat jelentős része elhullik. Az eredményeink alapján elmondható, hogy a vaddisznóskertben megnőtt az egyedek szociális interakciókkal töltött ideje, míg a táplálkozásra fordított idejük pedig jelentősen kevesebb volt. A kerti kocákat tekintve, jelentősen megnőtt agressziót figyelhettünk meg. Összességében elmondható, hogy a nagyobb állománysürüség okozta stressz a malacokra volt jelentős hatással, mely negatív hatások azonban eddigi vizsgálataink eredményei és javaslataink alapján csökkenthetőek lennének.
\end{abstract}

Kulcsszavak: szociális viselkedés, táplálék kompetíció, állatjólét, agresszió, vaddisznós kert.

\section{Bevezetés}

A társas életet élő állatok körében a csoporton belül a fajra jellemző szociális rendnek kell kialakulnia, különben a közösség a legrövidebb idön belül felbomlana (MEYNHARDT 1986). A hierarchia a csoportban előre meghatározza az egyedek számára a források hasznosíthatóságát (HAGELSÖ GIERSING \& STUDNITZ 1996) a rangsorban elfoglalt helyükhöz kötődő viselkedéselemek által (például fenyegetés, behódolás, elkerülés). Egy zárt kertben azonban a források végesek, ami pedig növeli az egyedek közötti kompetíciót (táplálék - a helytelen takarmányozásnak és nagy állománysürüségnek köszönhetően a terület eltartóképessége folyamatosan csökken; búvóhely stb.), ez pedig szociális stresszt, agreszsziót válthat ki (HuGHES et al. 1997; MCGLONE 1985). Egy zárt helyen, ahol rangsoron kívüli, egymásnak idegen egyedeket társítanak, azok a hierarchia hiányában addig fognak 
harcolni, küzdeni egymással, amíg ki nem alakul a rangsor (MCBRIDGE et al. 1964; TURNER \& EDWARDS 2004). Az egyedek közötti agressziónak két típusát lehet kiemelni: elsőként az idegen egyedek közötti intenzív harcok egy rövid periódusát említhetjük meg (FRASER 1984; PUPPE 1998). Másodszor pedig egy hosszabb távú kompetíciót a táplálékért (EWBANK 1972), illetve más forrásokért. Az etetés alatti agresszivitást befolyásolhatja az is, hogy milyen nemủ egyedek vannak a kondában (RYDHMER et al. 2006; GRAVES 1984), valamint a takarmány kiszórásának módja, és a terület nagysága is (ÚJVÁRY 2007). Az idegen származású csoportok vagy egyedek még az etetőhelyeken sem keverednek; a vaddisznós kertekben az utólag betelepített vaddisznók sokszor olyan kemény ellenállásba ütköznek a már bentlakók részéröl, hogy a jövevényeket a küzdelemben megölik (PÁlL 1982). Az új szociális szituációknak való kitettség félelmet okozhat, ami pedig a menekülés lehetőségének hiányában verekedéshez vezet (ARCHER 1987).

A rendelkezésre álló terület nagysága befolyásolhatja az agresszió mértékét (AREY \& EDWARDS 1998). A verekedések száma a csoportban lévő egyedek számával arányosan nő (MORRISON et al. 2007). A nagyobb sürüség pedig hatással van a testtömeg alakulására, illetve a reprodukciós paraméterekre is (BORNETT et al. 2000, TURNER et al. 2000). A TURNER et al. (2001) által végzett vizsgálatokból is látszik, hogy már néhány egyeddel való eltérés is jelentősen befolyásolhatja az agresszió mértékét. Az alacsonyabb sủrüség zárt helyen az agresszió szintjének csökkentését jelentette (Kelly et al. 1980; MORRISON et al. 2003), vagy esetleg nem volt hatással az agresszióra (SPOOLDER et al. 2000).

Viselkedésbeli változást okozhat még az az eset, amikor a már meglévő csoportból egyedet (egyedeket) távolítanak el. Valószínüsíthető, hogy egy egyed eltávolítását követően a csoportban maradt egyedeknek egy új rangsort kell felállítaniuk (RYDHMER et al. 2006). EWBANK \& MEESE (1971) vizsgálatai szerint azonban egy egyed eltávolítása nincs hatással az agresszióra, a dominancia viszonyokra. A szállítás során is gondot okozhat az, hogy esetlegesen idegen egyedek kerülnek össze; a jobb kondícióban lévő, nagyobb testsúlyú egyedek sokkal agresszívabbak (BUSSE \& SHEA-MOORE 1999). Házi sertések vizsgálatai alapján a nagyobb méretủ egyedek többet verekednek, mint a kisebbek (ANDERSEN et al. 2000, D’ EATH 2002). Több kutatás is alátámasztja, hogy a testméretek, a testtömeg az, ami leginkább befolyásolja a verekedések kimenetelét (TURNER et al. 2006, BORBERG \& HOY 2009). HELD et. al (2002) vizsgálatai során szintén azt figyelhették meg, hogy a nehezebb testtömegủ egyedek mutatták a domináns viselkedési formákat.

A kocák által alkotott csoportokban az alárendelt kocáknak a domináns kocával szembeni elkerülő magatartása tartja fenn a hierarchiát (JENSEN 1982). A kisebb testtömegü kocák kerülik az összetüzéseket a nagyobb, domináns kocákkal szemben. IsON et al. (2010) vizsgálatai alapján azokat az emséket, amelyek a csoportosítás előtt magasabb pozíciót töltöttek be az akkori rangsorban, az összerakás után sokkal nagyobb stressz érte. Ennek okaként a hierarchiában való jelentős visszaesést nevezik meg. JARVIS et al. (2006) vizsgálatai alapján súlyos következménye lehet annak, ha a szülés elötti időben mozgatjuk, helyezzük át a kocákat. MEYNHARDT (1986) említést tesz a zárt területen élő vaddisznók felnevelési nehézségeiről. Ennek egyik okaként a terület „túlnépesedését” nevezi meg. Azt pedig teljesen természetellenesnek tartja, ha az ilyen korlátozott területen kanokkal együtt tartják őket, ugyanis a kanok, a búgás idejét leszámítva, egész évben kerülik a kondákkal való találkozást (BRIEDERMANN 1990). Továbbá, az erős vadászati nyomás a gyorsabb növekedésű és 
korábban ivaréretté váló egyedek felé szelektál (FOCARDI et al. 2008), így az év bármelyik szakában számíthatunk malacozásra.

Különböző alomból származó malacok összerakása során szintén számolnunk kell a megnövekedett agresszióval, ami akár az egészségi állapotukat is negatívan érintheti (O’CONELL et al. 2005). Az összerakás után lényegesen megnőhet a malacok közötti verekedések száma (D’EATH 2005). A domináns malacok sokkal aktívabbak, mivel (hasonlóan az adult egyedekhez) meg kell tudniuk tartani a rangsorban elfoglalt magasabb pozíciójukat. Ez pedig nagyobb fokú agresszivitásukban figyelhetö meg, így például több az általuk kezdeményezett verekedések száma, valamint ezekben a verekedésekben hosszabb ideig is vesznek részt (STUKENBORG et al. 2011).

A vizsgálattal célunk az volt, hogy összehasonlítsuk a szabadterületen és a vaddisznós kertben élő egyedek, kondák táplálkozási, valamint szociális viselkedését, ugyanis a fellelhető irodalmakat tekintve szinte kivétel nélkül házi sertésekkel (esetleg állatkerti kondákkal, SCHNEBEL \& GRISWOLD 1983) végzett vizsgálatok eredményei, valamint állategészségügyi (SUGÁR \& SZTOJKOV 2004), tartástechnológiai (JÁNOSKA 2004) leírások olvashatóak. Ehhez kapcsolódóan a következő kérdéseket fogalmaztuk meg:

1. Hogyan alakul a táplálkozással töltött idő a két vizsgált területtípust tekintve?

2. Van-e kimutatható különbség a szociális interakciókkal töltött időtartamok és azok gyakorisága tekintetében?

3. Milyen viselkedésbeli probléma (megváltozott viselkedésforma) okozhatja a szaporulatnak a vadászkertekben megfigyelhető magas elhullási arányát?

\section{Anyag és módszer}

\section{Vizsgálati területek}

A vizsgálatokat a Pilisi Parkerdő Zrt. Pilisszentkereszti Erdészet és a Pilisvölgye Vadásztársaság területén végeztük (1. ábra). A videófelvételeket a szabadterületi vaddisznóállományról, valamint az erdészet által üzemeltetett vaddisznóskertben található állományról készítettük. A Pilisszentkereszti Erdészet (6148,6 hektár) és a Pilisvölgye Vadásztársaság (8302 hektár) egymással szomszédos területek. Jellemzően hegyvidéki részek mezőgazdasági területekkel szabdalva. A vadaskert területe összesen 446,3 hektár (ebböl a vaddisznóskert területe 235,7 hektár), Piliscsaba, Piliscsév és Pilisszántó községhatárokban helyezkedik el. A kert területén található erdőállományok zöme elegyes erdő, ahol a kocsánytalan tölgy mindenhol elöfordul. A fafajok sokfélesége ellenére a vadaskertek erdörészletei jobbára gyenge, közepes vadeltartóképességüek, a vadállományt kiegészítő takarmányozással tartják fenn. A vadaskert területén természetes vízfolyás nem található. A vaddisznóskertben három mesterséges dagonya és egy fúrt kút található. A nyári időszakban ezek a dagonyák kiszáradnak, ezért ilyenkor a vizet mesterségesen kell pótolni. 


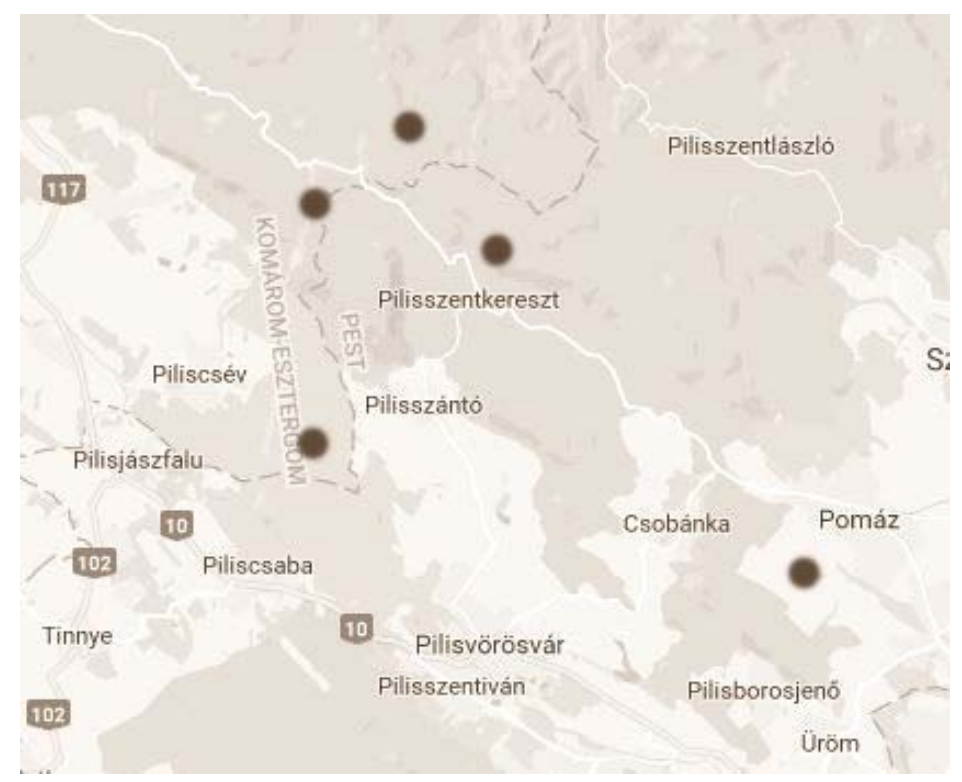

1. ábra. A vizsgálat helyszínei

Figure 1. The examination's locations

Az állománynagyság és az etetők, szórók száma közötti kapcsolatban szabadterületen és kertben jelentős különbségeket fedezhetünk fel. Szabadterületen 46 szóró található, ez azt jelenti, hogy egy szóróra 16 egyed jut. Ezzel szemben a kertben három etetőhely van kialakítva, így a körülbelül 150 egyedet számláló kerti állomány esetén egy etetőhelyre 50 egyed jut.

A felvételek a 2011-2015 közötti időszakokban, május- augusztus hónapokban (nyári időszakban) készültek, a teljes felvett és elemzett időtartam 4 óra 16 perc volt. A szabadterületi szórókon (5 szóró) ezen időszak alatt vadászat nem folyt (vagyis ekkor etetőhelyként szolgáltak).

\section{A felvételek elemzése}

A vizsgálatok során a szórón megjelenő egyedekről ( $\mathrm{N}=301$ egyed), kondákról készültek videó felvételek egy táplálék-kompetíciós helyzetben. A felvételeken található egyedek viselkedése különböző, jól definiálható viselkedéselemek (1. Táblázat, ÚJVÁRY 2007, ÚJVÁRY et al. 2012) szerint került kódolásra, viselkedéselemző program használatával (Solomon Coder). Ennek segítségével megkaptuk a különböző magatartásformák egyedenkénti időtartamát, továbbá ezek gyakoriságát. A változók eloszlásának normalitását Kolmogorov-Smirnov teszttel vizsgáltuk. A szabadterületi és kerti vaddisznóállomány egyedei viselkedésének összehasonlításához t-tesztet alkalmaztunk. A két vizsgált területen előforduló viselkedéselemek egymáshoz való viszonyát ANOVA-val vizsgáltuk. 
1. táblázat A viselkedéselemek meghatározása (ÚJVÁRY 2007).

Table 1. The behaviour elements' definition (ÚJVÁRY 2007).

\begin{tabular}{|c|c|}
\hline \multicolumn{2}{|c|}{ Domináns } \\
\hline Arrébb lökés & $\begin{array}{l}\text { A fókusz-állat fejével, csukott szájjal a másik tes- } \\
\text { tére ütő vagy toló mozdulatot tesz, amitől a másik } \\
\text { kibillenhet az egyensúlyából. }\end{array}$ \\
\hline Felémozdulás & $\begin{array}{l}\text { Csukott vagy nyitott szájjal a másik egyed felé } \\
\text { irányuló, max. } 2 \text { másodpercig tartó gyors közele- } \\
\text { dés. Az elmozdulás } 1 \mathrm{~m} \text {-en belül történik. }\end{array}$ \\
\hline Felérohanás & $\begin{array}{l}\text { Csukott vagy nyitott szájjal a másik egyed felé } \\
\text { irányuló, max. } 2 \text { másodpercig tartó gyors közele- } \\
\text { dés. Az elmozdulás } 1 \mathrm{~m} \text {-nél távolabbra történik. }\end{array}$ \\
\hline Kergetés & $\begin{array}{l}\text { Csukott vagy nyitott szájjal a másik egyed felé } \\
\text { irányuló, } 2 \text { másodpercnél tovább tartó gyors kö- } \\
\text { zeledés. Farok töve az enyhén emelkedettől a víz- } \\
\text { szintesig állhat. Fizikai kontaktus nincs. }\end{array}$ \\
\hline \multicolumn{2}{|c|}{ Szubmisszív } \\
\hline Fejfelemelés & $\begin{array}{l}\text { A támadó fél irányába a fej feltartása hangadás- } \\
\text { sal, miközben testét összehúzza. Mellsö lábak } \\
\text { nyújtottak, hátsó lábak enyhén hajlítottak, fülek } \\
\text { normál állapotban, farok töve általában felfelé } \\
\text { vagy vízszintesen áll. Ebbőll a pozícióból vagy } \\
\text { kihátrál, vagy elmenekül, vagy ott hagyják. }\end{array}$ \\
\hline Elmozdulás & $\begin{array}{l}\text { A támadó félre való orientálással, attól való el- } \\
\text { mozdulás bármilyen irányba. Az eltávolodás tá- } \\
\text { volsága nem nagyobb 1-2 m-nél. Farokállás nem } \\
\text { jellemző. }\end{array}$ \\
\hline Elkerülés & $\begin{array}{l}\text { Fókusz-állat irányába passzív viselkedést mutató } \\
\text { egyed kikerülése irányváltoztatással vagy kihátrá- } \\
\text { lással, vagy az addigi tevékenység megszakítása a } \\
\text { másik egyed közeledésének hatására. Farokállás } \\
\text { nem jellemző. }\end{array}$ \\
\hline Menekülés & $\begin{array}{l}\text { Gyors eltávolodás a másik féltől agresszív visel- } \\
\text { kedés hatására } 2 \text { m-en túlra. Általában a menekü- } \\
\text { lö állat farokállása vízszintes. }\end{array}$ \\
\hline \multicolumn{2}{|c|}{ Semleges } \\
\hline Táplálkozás & $\begin{array}{l}\text { Fókusz-állat feje a kitett takarmány felett, miköz- } \\
\text { ben az orrával túrhat. }\end{array}$ \\
\hline Egyéb & $\begin{array}{l}\text { Fókusz állat viselkedése egyik kategóriába sem } \\
\text { sorolható be. }\end{array}$ \\
\hline
\end{tabular}




\section{Eredmények}

\section{Táplálkozással töltött idő}

A táplálkozással töltött időt tekintve egyedül a malacok $(\mathrm{N}=215)$ esetében volt szignifikáns különbség (2. ábra). Szabadterületen szórón töltött idejük csaknem teljes egészét táplálkozással töltötték $(92,75 \pm 16,95 \%)$, míg kertben ez jelentősen kevesebb időt tett ki $(78,17 \pm 20,12 \%)$, idejük csaknem egynegyedében a szórón kívül tartózkodtak (kanok: szabadterületen $61,25 \pm 40,37 \%$, kertben $64,63 \pm 29,08 \%, \mathrm{~N}=29$; kocák: szabadterületen 68,89 $\pm 27,03 \%$, kertben $69,84 \pm 19,79 \%, \mathrm{~N}=57)$.

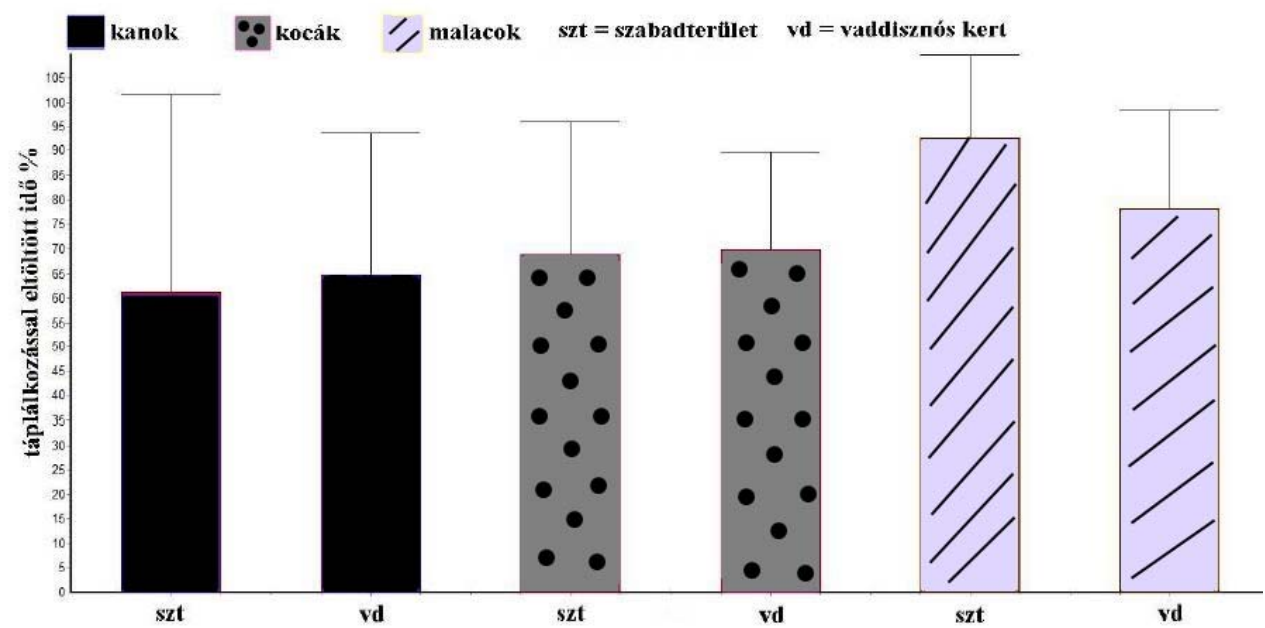

2. ábra. Táplálkozással töltött idő (\%)

Figure 2. Time spent with feeding $(\%)($ black $=$ males, dotted $=$ females, striped $=$ piglets, $\mathrm{szt}=$ open field, $\mathrm{vd}=$ preserve)

\section{Szociális interakciókkal töltött idö}

A szociális interakciókkal töltött idő (3. ábra) esetében szintén csak a malacoknál volt szignifikáns különbség kimutatható. Szabadterületen a malacok idejük $0,26 \pm 0,54 \%$-át jelentették az interakciók, míg kertben $(0,65 \pm 0,77 \%)$ ez több mint kétszerese volt (kanok: szabadterületen $0,28 \pm 0,53 \%$, kertben $0,85 \pm 0,81 \%$; kocák: szabadterületen $1,21 \pm 2,02 \%$, kertben $2,29 \pm 1,62 \%$ ). 


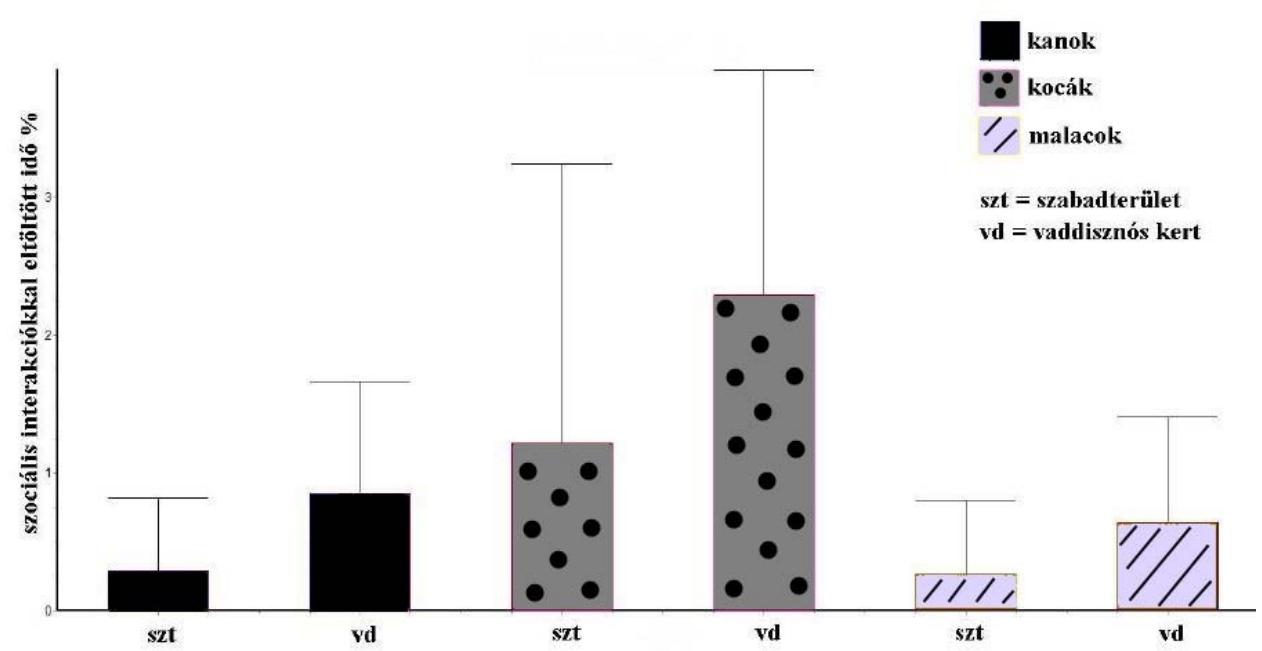

3. ábra. Szociális interakciókkal töltött idő (\%)

Figure 3. Time spent with social interactions (\%)(black= males, dotted= females, striped $=$ piglets, $\mathrm{szt}=$ open field, $\mathrm{vd}=$ preserve $)$

\section{Szociális interakciók száma}

Szignifikáns különbség mutatható ki a két terület között a szociális interakciók számát $(\mathrm{N}=291)$ tekintve egy egyedre és 10 percre vonatkoztatva (kertben 2,3-szer több mint szabadterületen). Szabadterületen ez az érték 1,34 $\pm 2,16$, míg kertben 3,16 \pm 1,61 (4. ábra).

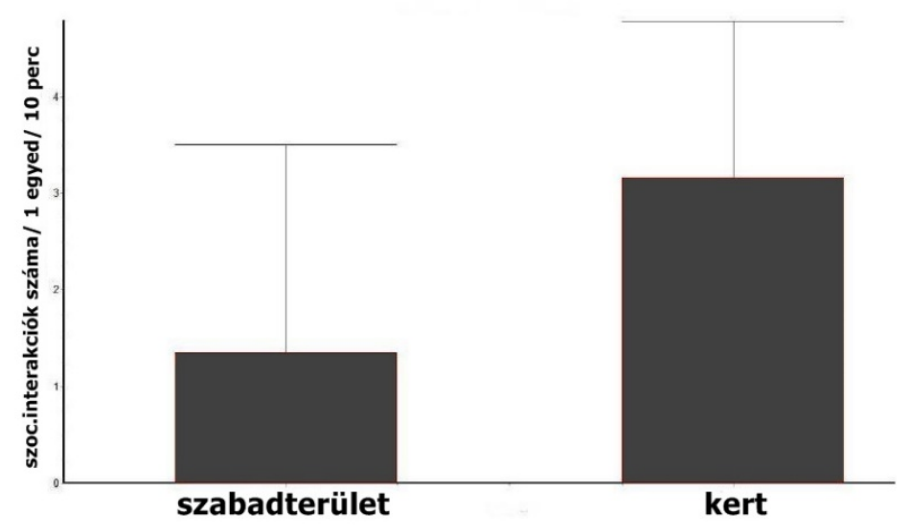

4. ábra Szociális interakciók száma / 1 egyed / 10 perc

Figure 4. Number of social interactions / 1 individual / 10 minutes in open field (left) and in preserves (right) 


\section{A domináns és szubmisszív elemekkel töltött idó}

Összehasonlítva a két vizsgált területtípust, megállapítható, hogy minden egyes vizsgált viselkedéselemmel töltött idő jelentősen több volt kertben (a menekülés, mint a legerősebb behódoló elem ideje kiugróan több kertben), de szignifikáns különbség csak a következő elemek esetén volt kimutatható (5. ábra):

Domináns elemek: felémozdulás $(p=0,0023)$, felérohanás $(p=0,0044)$, és kergetés $(\mathrm{p}=0,0425)$.

Szubmisszív elemek: elmozdulás $(\mathrm{p}=0,0147)$ és menekülés $(\mathrm{p}<0,0001)$.

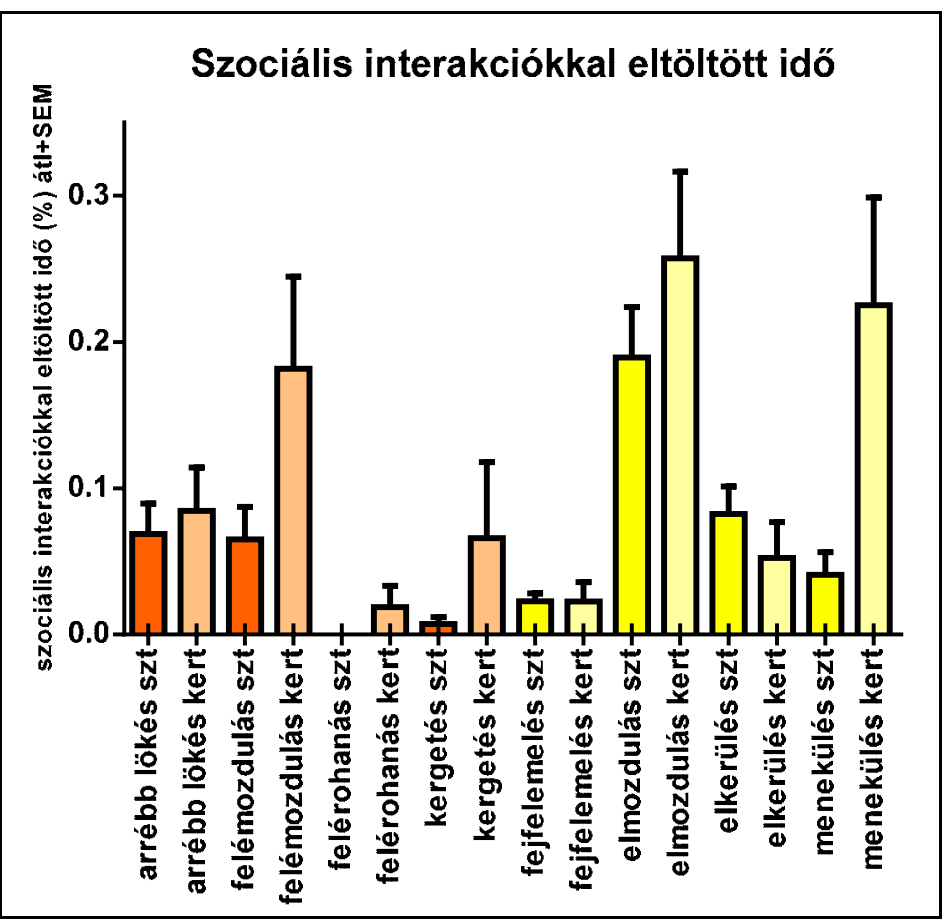

5. ábra A domináns és szubmisszív elemekkel töltött idő (\%)

Figure 5. Time spent with dominant and submissive elements $(\%)(\mathrm{szt}=$ open field, $\mathrm{kert}=$ preserve $)$

\section{Menekülés gyakorisága}

Szignifikáns különbség volt kimutatható (6. ábra) a menekülés gyakoriságát tekintve 1 egyedre és 10 percre vonatkoztatva kondánként ( $\mathrm{N}=301)$. Szabadterületen jelentősen kevesebbszer jelent meg a legerősebb szubmisszív elem, mint a vaddisznós kertben (szabadterületen: $0,05 \pm 0,02 \mathrm{darab} / 1$ egyed/10 perc; kertben: $0,42 \pm 0,13 \mathrm{darab} / 1$ egyed/10 perc). 


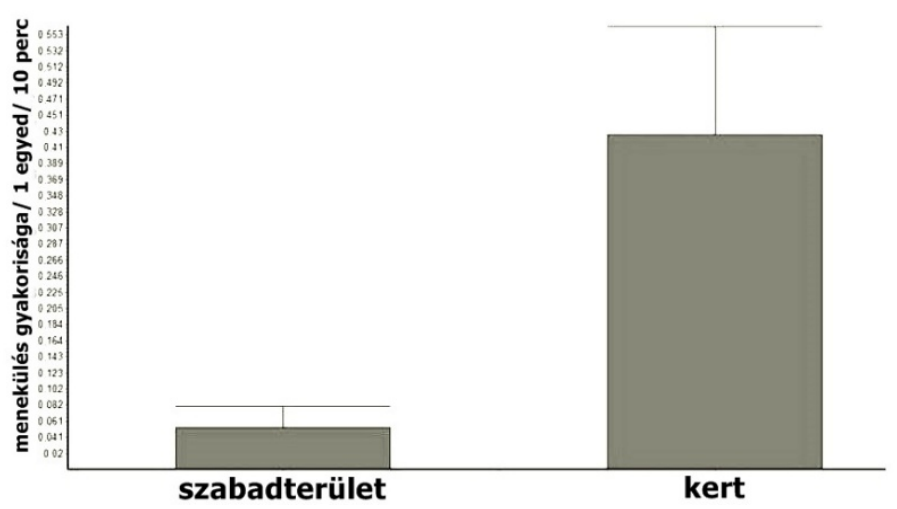

6. ábra A menekülés gyakorisága / 1 egyed / 10 perc

Figure 6. Frequency of escape $/ 1$ individual $/ 10$ minutes (szabadterület $=$ open field, kert= preserve)

\section{Értékelés}

A kerti és szabadterületi vizsgálatok eredményei alapján elmondhatjuk, hogy a vaddisznóskertben az állatok kimutathatóan több szociális interakciót mutattak, mint szabad területi társaik, a táplálkozásra fordított idejük az etetőhelyeken pedig kevesebb volt. A malacok esetében volt egyedül szignifikáns különbség a táplálkozást vizsgálva a két terület között. A vaddisznóskertben az etetöhelyen töltött idejüknek közel 22\%-át nem táplálkozással töltötték (szemben a szabadterület közel 7\%-ával). Azonban az is igaz, hogy a malacoknál volt a legkevesebb a szociális interakciókkal töltött idő. Tehát az esetükben ezt a fennmaradó $22 \%$-ot nem csak az interakciók teszik ki, hanem elkerülve a konfliktusokat az idősebb, adult egyedekkel, jelentős időt töltöttek inkább az etetőt körülvevő takarásban, cserjésben, miközben a kiegészítő takarmányozással célunk az lenne, hogy a kertben lévő egyedek minél több és minél jobb minőségü táplálékot vegyenek fel. PALKOVICS et al. (1988) tapasztalataik alapján ezt a malacokkal járó sok kocával magyarázza, mivel így a malacok nem jutnak egyenletesen takarmányhoz, ha az etetők száma kevés. Eredményeink alapján azonban nem volt kimutatható kapcsolat a kocák száma és a velük lévő malacok táplálkozással, valamint szociális interakcióikkal tölttött ideje között, vagyis a kocák száma alapvetỏen nem befolyásolja a malacok viselkedését, a kocák által kezdeményezett interakciók jelentős része adult egyedek felé irányult.

Szabadterületen átlagosan több malac $(10,11 \pm 6,38)$ volt megfigyelhető egy kondán belül, mint kertben $(5,66 \pm 3,61)$, ennek egyik lehetséges oka a kevesebb szociális interakció lehet, a kevesebb agresszió, stressz miatt jobb lehet a kocák nevelési sikere. Az átlagos konda méretet tekintve nem volt eltérés a két terület között, azonban szabadterületen a legnagyobb konda 30 egyedből állt, míg kertben csak 14 egyedből (legkisebb kondaméret 5, illetve 6 egyedből állt); a szabadterületi nagy létszámú kondákban a malacok száma jelentős volt (20-25 malac is akár). 
Mindkét területen a kocák töltötték a legtöbb időt interakciókkal, a kertben élő kocák voltak azonban a legagresszívabbak. Ennek hátterében az állhat, hogy nem társulnak szívesen egymással zárt helyen. Ezt támaszthatja alá az is, hogy a kerti kondákban lévő kocák száma $(0,66 \pm 0,81)$ jelentősen kevesebb volt a szabadterületi kondákban $(2,42 \pm 1,77)$ lévőkénél. RYDHMER et al. (2006) házi sertéseknél azt tapasztalták, hogy az egy karámban tartott kocák és kanok közül a kocák kevesebbszer mutattak agresszív viselkedést, mint a kanok, de nem találtak szignifikáns különbséget az őket ért támadások számát tekintve. Viszont abban a karámban, ahol csak kocák voltak, ott többször támadtak egymásra, mint a vegyes karámban (a kanok esetében ezt nem lehetett kimutatni). Ezzel szemben egy másik, szintén házi sertésre vonatkozó vizsgálat során az egynemü karámokban a kanok sokkal nagyobb agresszivitást mutattak, mint a kocák (SALMON \& EDWARDS 2006). GIERSING \& ANDERSSON (1998) vizsgálatainak eredménye eltérő, mely szerint ugyanolyan gyakori a kocák és a kanok között is az agresszió, azonban egy kan és egy koca között a kan által kezdeményezett agresszió sokkal gyakrabban fordul elö. PALKOVICS et al. (1988) a kertben lévő kocák esetén megemlíti, hogy az etetőhelyekről az idősebb kocák kiszoríthatják a fiatalabbakat; ez pedig csökkent reprodukcióhoz vezethet (MENDL et al. 1992).

Külön ki kell térni a menekülés gyakoriságának fontosságára, ugyanis ez több viselkedésbeli változásra is felhívhatja a figyelmet. Egyrészt feltételezi a kerti egyedek nagyobb fokú érzékenységét az agresszív viselkedésre, azaz már egy kismértékü (jóformán csak „ijesztgető” jellegü) agresszív viselkedésre is nagyobb eséllyel válaszolnak behódoló, elkerülő viselkedéssel. Másrészről viszont a menekülési viselkedés megnövekedett gyakoriságát okozhatja az agresszió nagyobb mértékủ megnyilvánulása is, azaz jelentősen többször fordul elö, olyan helyzetekben is, amikor szabadterületen nem jelenne meg.

Jellemzőek voltak a vizsgálat időszakára a rendszeres befogások (egy vaddisznóskertben lényegében nincsenek nyugalmi időszakok - késő tavasztól megkezdődnek a befogások, egészen a vadászatokig, melyek pedig egész télen át tarthatnak). A befogott egyedek jelentős része még malac volt, sok esetben az anyjuk nélkül kerültek befogásra, majd a kertbe is. Emiatt már eleve vesztes pozícióból indultak a már bent lévő felnőtt egyedekkel, kondákkal szemben az etetőhelyeken. A vizsgálat eredményeit figyelembe véve (KovÁCS 2015), érdemes lenne a vaddisznós kertben több etetőhelyet is kialakítani (külön a malacoknak is, vagyis egy olyan berendezést, amelyhez nem férhetnek hozzá a felnőtt egyedek), és azokat jobban kihasználni mind időben (akár napi rendszerességgel történő etetés, megfelelő mennyiségü és minőségü takarmánnyal, befogási időszakban különösen fontos lehet), mind etetési módokban (a különbözö etetési elrendezések hatással lehetnek az agresszió mértékére, ÚJVÁRY 2015). Továbbá a befogott malacokat érdemes lenne először falkásítani, azaz a koca nélkül befogott malacokat elöször összeszoktatni egy erre kijelölt helyen (malacnevelöben), és csak ezt követően áthelyezni a vadászkertbe. Az etetőhelyeken az egyedek viselkedésének folyamatos nyomon követésével lehetne korrigálni az etetések mennyiségét, az etetőhelyek számát, valamint a" problémás" (beilleszkedni képtelen vagy legyengült) egyedeket kiemelni. Ugyanis az eredmények arra utalnak, hogy vaddisznós kertben a nagyobb egyedsürüség szociális stresszt okozhat, ami elsősorban a malacokat érinti hátrányosan; ez pedig magyarázhatja a malacok nagyobb elhullási arányát a kertben. 
Köszönetnyilvánítás. Köszönet illeti a Pilisvölgye Vadásztársaság, valamint a Pilisi Parkerdő Zrt-t, hogy lehetővé tették területükön a felvételek elkészítését.

\section{Irodalomjegyzék}

Andersen, I. L., Andenaes, H., Boe, K. E., Jensen, P. \& Bakken, M. (2000): The effects of weight asymmetry and resource distribution on aggression in groups of unacquainted pigs. Applied Animal Behaviour Science 68: 107-120. https://doi.org/10.1016/S0168-1591(00)00092-7

ARCHER, J. (1987): The behavioural biology of aggression. Cambridge University Press, Cambridge, London, $255 \mathrm{pp}$.

AREY, D. S. \& EDWARDS, S. A. (1998): Factors influencing aggression between sows after mixing and the consequences for welfare and production. Livestock Production Science 56: 61-70. https://doi.org/10.1016/S0301-6226(98)00144-4

Borberg, C. \& Hoy, S. (2009): Mixing of sows with or without the presence of boar. Livestock Production Science 125: 314-317. https://doi.org/10.1016/j.livsci.2009.04.008

Bornett, H. L. I., Morgan, C. A., LAwrence, A. B. \& MAnN, J. (2000): The effect of group housing on feeding patterns and social behaviour of previously individually housed growing pigs. Applied Animal Behaviour Science 70: 127-141. https://doi.org/10.1016/S0168-1591(00)00146-5

BriedermanN, L. (1990): Schwarzwild. Neumann-Neudamm, Melsungen. 2nd edition. 539 pp

Busse, C. S., \& SHEA-Moore, M. M. (1999): Behavioural and physiological responses to transportation stress. Journal of Animal Science 77(1): 147.

D'EATH, R. B. (2002): Individual aggressiveness measured in a resident-intruder test predicts the persistence of aggressive behaviour and weight gain of young pigs after mixing. Applied Animal Behaviour Science 77: 267-283. https://doi.org/10.1016/S0168-1591(02)00077-1

D'EATH, R. B. (2005): Socialising piglets before weaning improves social hierarchy formation when pigs are mixed post-weaning. Applied Animal Behaviour Science 93: 199-211. https://doi.org/10.1016/j.applanim.2004.11.019

Ewbank, R. (1972): Social environment of the pig. In: Cole D. J. A. (ed.): Pig production. Pennsylvania State University Press pp. 129-139.

EwbAnK, R. \& MEESE, G. B. (1971): Aggressive behaviour in groups of domesticated pigs on removal and return of individuals. Animal Production 13: 685-695. https://doi.org/10.1017/S0003356100000179

FoCARDI, S., GAILlARD, J-M., RONCHI, F. \& Rossi, S. (2008): Survival of wild boars in a variable environment: unexpected life-history variation in an unusual ungulate. Journal of Mammalogy 89 (5): 1113-1123. https://doi.org/10.1644/07-MAMM-A-164.1

FRASER, D. (1984): The role of behaviour in swine production: A review of research. Applied Animal Ethology 11: 317-339. https://doi.org/10.1016/0304-3762(84)90041-5

GIERSING, M. \& ANDERSSON, A. (1998): How does former acquaintance affect aggressive behaviour in repeatedly mixed male and female pigs? Applied Animal Behaviour Science 59: 297-306. https://doi.org/10.1016/S0168-1591(98)00141-5

Graves, H. B. (1984): Behavior and ecology of wild and feral swine (Sus scrofa). Journal of Animal Science 58: 482-492. https://doi.org/10.2527/jas1984.582482x

Hagelsö Giersing, M. \& Studnitz, M. (1996): Characterization and investigation of aggressive behaviour in the pig. Acta Agriculturae Scandinavica Section A, Animal Science 27: 56-60. 
Held, S., Mendl, M., Laughlin, K. \& Byrne, W. (2002): Cognition studies with pigs: Livestock cognition and its implication for production. Journal of Animal Science 80: E10-E17.

Hughes, B. O., Carmichael, N. L., Walker, A. W. \& Grigor, P. N. (1997): Low incidence of aggression in large flocks of laying hens. Applied Animal Behaviour Science 54: 215-234. https://doi.org/10.1016/S0168-1591(96)01177-X

Ison, S. H., D’EAth, R. B., Robson, S. K., MAXter, E. M., Ormandy, E., Douglas, A. J., Russell, J. A., LAWRENCE, A. B. \& JARVIS, S. (2010): Subordination style in pigs? The response of pregnant sows to mixing stress affects their offspring's behaviour and stress reactivity. Applied Animal Behaviour Science 124: 16-27. https://doi.org/10.1016/j.applanim.2010.02.001

JÁNOSKA, F. (2004): Vaddisznóskertek hazai tapasztalatai, perspektívái. In: Dr. Nagy Emil (szerk): Vaddisznó-gazdálkodásunk időszerü kérdései, konferencia, 2004. június 10., Nemzeti Ménesbirtok Kft központja, pp. 34-42.

Jarvis, S., Moinard, C., Robson, S.K., Baxter, E., Ormandy, E., Douglas, A. J., Seckl, J. R., Russele, J. A. \& Lawrence, A. B. (2006): Programming the offspring of the pig by prenatal social stress: neuroendocrine activity and behaviour. Hormones and Behaviour 49: 68-80. https://doi.org/10.1016/j.yhbeh.2005.05.004

JENSEN, P. (1982): An analysis of agonistic patterns in group-housed dry sows - aggression regulation through an avoidance order. Applied Animal Ethology 9: 47-61. https://doi.org/10.1016/03043762(82)90165-1

Kelly, K. W., McGlone, J. J. \& Gaskins, C. T. (1980): Porcine aggression: measurement and effects of crowding and fasting. Journal of Animal Science 50: 336-341. https://doi.org/10.2527/jas1980.502336x

KovÁcs, V. (2015): A vaddisznók szociális interakcióinak vizsgálata etetés közben, szabadterületen és vaddisznós kertben. Diplomadolgozat, Gödöllő, Szent István Egyetem, 62 pp.

McBridge, G., JAmes, J. W. \& Hodgens, N. (1964): Social behaviour of domestic animals. IV. Growing pigs. Animal Production 6: 129-139. https://doi.org/10.1017/S0003356100021887

MCGLONE, J. J. (1985): A quantitive ethogram of aggressive and submissive behaviours in recently regrouped pigs. Journal of Animal Science 61: 559-565. https://doi.org/10.2527/jas1985.613556x

Mendl, M., Zanella, A. J. \& Broom, D. M. (1992): Physiological and reproductive correlates of behavioural strategies in female domestic pigs. Animal Behaviour 44: 1107-1121. https://doi.org/10.1016/S0003-3472(05)80323-9

MEYNHARDT, H. (1986): Vaddisznóriport, életem a vaddisznók között. Gondolat, Budapest, 140 pp.

Morrison, R. S., Hemsworth, P. H., Cronin, G. M. \& CAmpbell, R. G. (2003): The social and feeding behaviour of growing pigs in deep-litter, large group housing systems. Applied Animal Behaviour Science 82: 173-188. https://doi.org/10.1016/S0168-1591(03)00067-4

Morrison, R. S., Johnston, L. J. \& Hilbrands, A. M. (2007): The behaviour, welfare, growth performance and meat quality of pigs housed in a deep-litter, large group housing system compared to a conventional confinement system. Applied Animal Behaviour Science 103: 12-24. https://doi.org/10.1016/j.applanim.2006.04.002

O’CONELl, N. E., BEATTIE, V. E. \& WATT, D. (2005): Influence of regrouping strategy on performance, behaviour and carcass parameters in pigs. Livestock Production Science 97: 107-115. https://doi.org/10.1016/j.livprodsci.2005.03.005

PAlkovics, GY., BÜKI, L. \& EgYed, I. (1988): A vaddisznó zárttéri tartása. Magyar Távirati Iroda, Budapest, $111 \mathrm{pp}$.

PÁLl, E. (1982): A vaddisznó és vadászata. Mezőgazdasági Kiadó, Budapest, 212 pp. 
PuPPE, B. (1998): Effects of familiarity and relatedness on agonistic pair relationships in newly mixed domestic pigs. Applied Animal Behaviour Science 58: 233-239. https://doi.org/10.1016/S01681591(98)00107-5

Rydhmer, L., Zamaratskaia, G., Andersson, H. K., Algers, B., Guillemet, R. \& Lundström, K. (2006): Aggressive and sexual behaviour of growing and finishing pigs reared in groups, without castration. Acta Agriculturae Scand Section A 56: 109-119. https://doi.org/10.1080/09064700601079527

SALMON, E. L. R. \& EDWARDS, S. A. (2006): Effects of gender contact on the behaviour and performance of entire boars and gilts from 60 to $130 \mathrm{~kg}$. In: B.S.o.A. Science (ed.) Proceedings British Society of Animal Science p. 72.

Schnebel, E. M. \& Griswold, J. G. (1983) Agonistic interactions during competition for different resources in captive European wild pigs (Sus scrofa). Appl. Anim. Ethol. 10: 291-300. https://doi.org/10.1016/0304-3762(83)90180-3

Spoolder, H. A. M., Edwards, S. A. \& Corning, S. (2000): Legislative methods for specifying stocking density and consequences for the welfare of finishing pigs. Livestock Production Science 64: 167-173. https://doi.org/10.1016/S0301-6226(99)00152-9

Stukenborg, A., Traulsen, I., Puppe, B., Presuhn, U. \& Krieter, J. (2011): Agonistic behaviour after mixing in pigs under commercial farm conditions. Applied Animal Behaviour Science 129: 28-35. https://doi.org/10.1016/j.applanim.2010.10.004

SugÁr, L. \& SzTOJKov, V. (2004): Az intenzív vaddisznótartás állategészségügyi kérdései. In: Dr. Nagy Emil (szerk):Vaddisznó-gazdálkodásunk időszerü kérdései, konferencia, 2004. június 10., Nemzeti Ménesbirtok Kft központja, pp. 43-47.

Turner, S. P., Ewen, M., Rooke, J. A. \& Edwards, S. A. (2000): The effect of space allowance on performance, aggression and immune competence of growing pigs housed on straw deep-litter at different group sizes. Livestock Production Science 66: 47-55. https://doi.org/10.1016/S03016226(00)00159-7

TURNER, S. P., Horgan, G. W. \& EdWARDS, S. A. (2001): Effect of social group size on aggressive behaviour between unacquainted domestic pigs. Applied Animal Behaviour Science 74: 203-215. https://doi.org/10.1016/S0168-1591(01)00168-X

TuRner, S. P. \& EDWARDS, S. A. (2004): Housing immature domestic pigs in large social groups: implications for social organisation in a hierarchical society. Applied Animal Behaviour Science 87: 239-253. https://doi.org/10.1016/j.applanim.2004.01.010

Turner, S. P., Farnworth, M. J., White, I. M. S., Brotherstone, S., Mende, M., KnaP, P., Penny, P. \& LAwrence, A. B. (2006): The accumulation of skin lesions and their use as a predictor of individual aggressiveness in pigs. Applied Animal Behaviour Science 96: 245-259. https://doi.org/10.1016/j.applanim.2005.06.009

ÚJVÁRY, D. (2007): Területcsökkentés hatásának vizsgálata fogságban tartott vaddisznóknál egy táplálék-kompetíciós helyzetben. Szakdolgozat, Szent István Egyetem, Vadvilág Megőrzési Intézet, $62 \mathrm{pp}$.

ÚJVÁRY, D.; HoRVÁth, Zs. \& SzEMETHY, L. (2012): Effect of area decrease in a food competition situation in captive wild boars (Sus scrofa). Journal of Veterinary Behavior 7(4): 238-244. https://doi.org/10.1016/j.jveb.2011.06.003

ÚJVÁRY, D. (2015): Szociális interakciók hatása a zárttéri vaddisznótartásra. Doktori (PhD) értekezés. Gödöllö, Szent István Egyetem, 104 pp. 


\title{
The wild boar's (Sus scrofa) behavioural problems in wild boar preserves

\author{
VIRÁG KOVÁCS ${ }^{1 *}$ DÓRA ÚJVÁRY ${ }^{2} \&$ LÁSZLÓ SZEMETHY ${ }^{1}$ \\ ${ }^{1}$ Institute for Wildlife Conservation, Szent István University, Páter Károly u. 1, \\ H-2103 Gödöllő, Hungary, ${ }^{*}$ E-mail: kowirag@gmail.com \\ ${ }^{2}$ Horkai Animal Training Center, Visegrádi u. 53, H-1132 Budapest, Hungary
}

\section{ÁLLATTANI KÖZLEMÉNYEK (2016) 101(1-2): 65-78.}

\begin{abstract}
Wild boar means a substantial income for the wildlife-management in Hungary, its population continously growing; nonetheless, there is a demand for the wild boars' hunting in preserves. But the operators must keep wild boars in large density to provide huge bag. In a wild boar preserve (for hunting) or in a farm (for meat production), there are special living conditions, that will cause changes in the behaviour of individuals. The animal welfare is maybe the main factor in livestock breeding, including keeping wild animals. The aim of the present study was to examine the behavioural changes of wild boars (Sus scrofa) in preserve compared to open field. We used in all cases hand cameras in a food competition situation at food placements. The behaviour of individuals was coded already based on specific behaviour elements and we defined the dominant and submissive elements' frequency, and the proportion of feeding and social interactions. The behaviour elements were dominant (push away somebody moving toward sy, running toward sy, chasing), submissive (head lift, displacement, avoidance, escape) and neutral (feeding and other). There was significant differences between the feeding's period in open field and in wild boar preserve. The members of the groups in open field could eat much more at feeders than the members of wild boar preserve. In preserve, the time of social interactions was significantly more, than in open field. Piglets could eat significantly less in preserves, and time of social interactions was significantly more than in open field. Sows spent the most time with social interactions in both areas, but it was significantly higher in the wild boar preserve.
\end{abstract}

Keywords: Sus scrofa, social behaviour, food competition, welfare, aggression, preserve. 